\title{
Effects of isotretinoin use on vocal fold mucosa: An experimental study
}

\section{İzotretinoin kullanımının vokal kord mukozası üzerindeki etkileri: Deneysel çalışma}

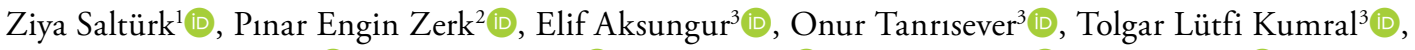 \\ Belgin Tutar ${ }^{3}$ (D), Güler Berkiten ${ }^{3}$, Yavuz Atar $^{3}$ (D), Hüseyin Sarı ${ }^{3}$, Yavuz Uyar ${ }^{3}$ (D) \\ ${ }^{1}$ Department of Otolaryngology, Anadolu Sağlik Center, Istanbul, Turkey \\ ${ }^{2}$ Department of Pathology, Prof. Dr. Cemil Taşcıoğlu City Hospital, Istanbul, Turkey \\ ${ }^{3}$ Department of Otolaryngology, Prof. Dr. Cemil Taşcıoğlu City Hospital, Istanbul, Turkey
}

\section{ABSTRACT}

Objectives: This study aims to examine vocal fold epithelial changes related to use of isotretinoin.

Materials and Methods: Between April 15, 2019 and May 15, 2019, a total of 12 healthy adult female Wistar albino rats (aging 7 to 8 months, weighing 200 to $250 \mathrm{~g}$ ) were used in this study. Totally, 0.5 to $1 \mathrm{mg} / \mathrm{kg} /$ day isotretinoin was given, orally by gavage, to eight Wistar albino rats in the experimental group. The four rats in the control group were not administered any drugs and were observed during for four weeks. A histopathological examination was performed to evaluate the presence of epithelial inflammation, keratosis, atrophy, and necrosis in the vocal fold epithelium.

Results: The extent of inflammation did not significantly differ between the two groups. All epithelial linings from both groups showed epithelial atrophy. The experimental group showed orthokeratotic hyperkeratosis in all the vocal folds. The granular layer was also increased in all of these vocal folds. None of these changes were observed in the vocal folds of the control group.

Conclusion: A four-week isotretinoin treatment increased the granular layer of the epithelium and keratosis in the vocal folds of rats.

Keywords: Adverse effects, isotretinoin, mucosa, vocal fold.
$\ddot{O} Z$

Amaç: Bu çalışmada izotretinoin kullanımı ile ilişkili vokal kord epiteli üzerindeki değişiklikler incelendi.

Gereç ve Yöntemler: Bu çalışmada 15 Nisan 2019 - 15 Mayıs 2019 tarihleri arasında 12 sağlıklı erişkin dişi Wistar albino sıçan (yaş 7 to 8 ay, ağırlık 200 to 250 g) kullanıldı. Deney grubundaki sekiz Wistar albino sıçana, oral olarak gavaj yoluyla toplam 0.5 ila $1 \mathrm{mg} / \mathrm{kg} /$ gün izotretinoin verildi. Kontrol grubundaki dört sıçana herhangi bir ilaç verilmedi ve dört hafta boyunca takip edildi. Vokal kord epitelinde meydana gelen epitelyal enflamasyon, keratoz, atrofi ve nekroz varlığını değerlendirmek için histopatolojik inceleme yapıldı.

Bulgular: Enflamasyon derecesi açısından iki grup arasında farklılık gözlenmedi. Her iki grupta tüm epitelyal katmanlarda epitelyal atrofi izlendi. Deney grubunda tüm vokal kordlarda ortokeratotik hiperkeratoz saptand. Granüler tabaka da, bu vokal kordların tümünde artmıştı. Kontrol grubunun vokal kord epitelinde bu değişikliklerin hiçbiri gözlenmedi.

Sonuç: Dört haftalık izotretinoin tedavisi, sıçanlarda epitelin granüler tabakasını ve vokal kordların keratozunu artirdi.

Anahtar sözcükler: Advers etkiler, izotretinoin, mukoza, vokal kord.

Received: July 23, 2020 Accepted: October 25, 2020 Published online: March 02, 2021

Correspondence: Ziya Saltürk, MD. Anadolu Sağlık Merkezi, Kulak Burun Boğaz Bölümü, 34746 Ataşehir, İstanbul, Türkiye. e-mail: ziyasalturk@gmail.com 
Systemic administration of isotretinoin is a revolutionary development in acne treatment, and it has been used clinically for about 35 years. ${ }^{[1,2]}$ Isotretinoin is a synthetic vitamin A analog which suppresses the sebaceous gland activity and microbial colonization. ${ }^{[3,4]}$ The most common adverse effects of isotretinoin are mucocutaneous changes including dry skin, dry eyes, and nasal changes. ${ }^{[5-9]}$ Other adverse effects include gastrointestinal, hepatic, hematological, skeletal, and neurological problems. ${ }^{[10]}$

Although it seems that isotretinoin use is not an important problem for voice problems, case reports have been published on this topic. ${ }^{[11-13]}$ In addition, the Owners' Manual to the Voice for singers states that isotretinoin use can cause loss of agility, breathy tone, and loss of high notes. ${ }^{[14]}$

To the best of our knowledge, there has been no previous reports on the effects of isotretinoin on the healthy larynx in the English literature. However, there have been studies on the efficacy of isotretinoin use on laryngeal papillomatosis and the prevention of the recurrence of head and neck cancers, implying some benefits of its use. ${ }^{[17]}$ As epithelial surfaces are the main tissues affected by the adverse effects of isotretinoin, the vocal folds and, specifically, their vibratory function may be affected during treatment. In the present study, we aimed to examine vocal fold epithelial changes related to use of isotretinoin in a rat model.

\section{MATERIALS AND METHODS}

This experimental study was approved by the Istanbul Bezmialem University Experimental Animal Research Ethics Committee (date/no: 2019/21) and conducted in the animal experiment laboratory of the institution.

Between April 15, 2019 and May 15, 2019, a total of 12 healthy adult female Wistar albino rats (aging 7 to 8 months, weighing 200 to $250 \mathrm{~g}$ ) were used in the study. Eight Wistar albino rats in the experimental group were given 0.5 to $1 \mathrm{mg} / \mathrm{kg} / \mathrm{day}$ isotretinoin, which was administered orally by gavage for four weeks. The dose was split into two equivalent doses and administered in the morning and evening. The four rats in the control group were not administered any drugs and were only observed for four weeks. All animals had free access to food and water ad libitum. They were kept under controlled environmental conditions of $25^{\circ} \mathrm{C}$ under a $12-\mathrm{h}$ light-dark cycle. At the end of four weeks, the rats were sacrificed with high-dose ketamine $(150 \mathrm{mg} / \mathrm{kg})$ anesthesia. The larynges of all animals were removed intact and stored in $10 \%(\mathrm{v} / \mathrm{v})$ buffered in formalin solution and, then, were evaluated by an expert pathologist. The specimens were cut into 5-mm-thick sections. Standard tissue processing methods were performed, and the sections were stained with hematoxylin and eosin. A histopathological examination was performed to evaluate the presence of epithelial inflammation, keratosis, atrophy, and necrosis in the vocal fold epithelium.

\section{Statistical analysis}

Study power and sample size calculation were performed using the $\mathrm{G}^{*}$ Power version 3.1 software (Heinrich-Heine Universität Düsseldorf, Düsseldorf, Germany). The type 1 error rate was set at 0.05 with a confidence interval (CI) of 95\%. The type 2 error rate was set at 0.2 with a $\mathrm{CI}$ of $80 \%$. Accordingly, the desired sample size was six for each group. No statistical analysis was performed in the study.

\section{RESULTS}

This experimental study was completed with 12 rats per protocol. A total of 300 specimens were evaluated histopathologically. The scores of the histopathological parameters are given in Table 1 . No macroscopic differences were evident between the larynges of the experimental and control groups. However, microscopically, three types of epithelial cells were detected in the vocal folds of the control group. The ventral part of the glottis was composed of striated ciliary epithelium adjacent to the loose connective tissue. The free margins of the vocal folds and adjacent areas were covered by striated non-ciliated columnar epithelia. The arytenoid region and adjacent areas were covered by striated squamous epithelia that were thinner on the arytenoid cartilage. The experimental group exhibited similar histopathological features.

Both groups exhibited typical epithelial linings and basal membranes. The extent of inflammation on the

\begin{tabular}{|ccc|}
\multicolumn{4}{c|}{ Table 1} \\
Pathological examination results of chronic inflammation \\
\hline & Study Group & Control Group \\
\hline Animal & & \\
1 & + & + \\
2 & + & + \\
3 & + & + \\
4 & + & \\
5 & + & \\
6 & + & \\
7 & + & \\
8 & + & \\
\hline
\end{tabular}




\begin{tabular}{|ccc|}
\multicolumn{4}{c|}{ Table 2 } \\
\multicolumn{4}{|c|}{ Pathological examination results of epithelial atrophy } \\
\hline & Study Group & Control Group \\
\hline Animal & + & + \\
1 & + & + \\
2 & + & + \\
3 & + & + \\
4 & + & \\
5 & + & \\
6 & + & \\
7 & + &
\end{tabular}

vocal cord epithelial did not significantly differ between the two groups (Table 1). All epithelial linings from both groups showed epithelial atrophy (Table 2). The results were similar in all rats.

The study group showed orthokeratotic hyperkeratosis in all the vocal folds (Figure 1). The

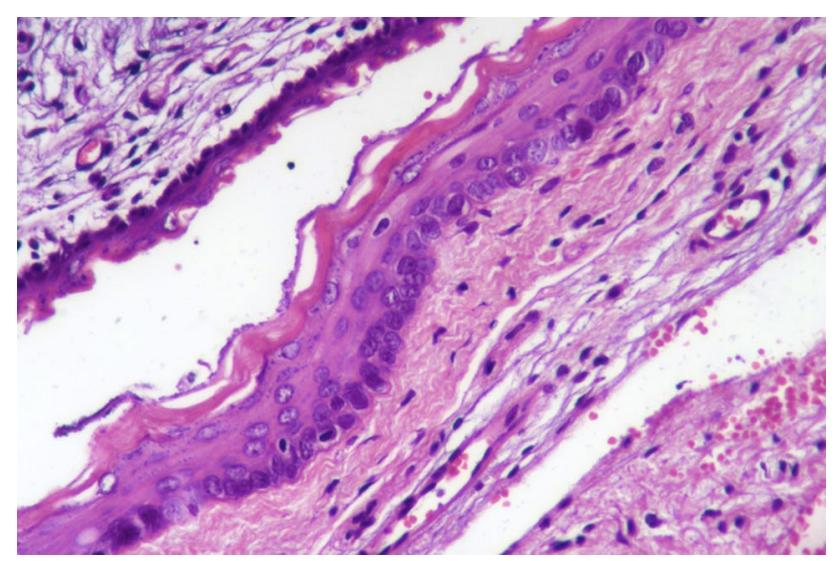

Figure 1. Orthokeratotic hyperkeratosis $(\mathrm{H}-\mathrm{E}, \times 400)$.

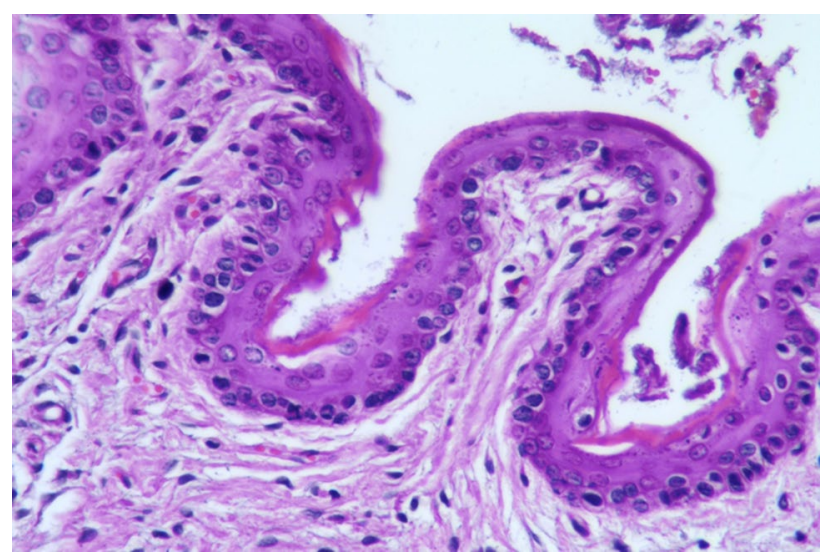

Figure 2. Granular layer increase $(\mathrm{H}-\mathrm{E}, \times 200)$. granular layer also increased in all of these vocal folds (Table 3 and Figure 2). None of the vocal folds in the control group showed these changes (Table 3 and Figure 3 ). No necrosis was found in any of the laryngeal specimens.

\section{DISCUSSION}

The vocal fold is composed of epithelial, lamina propria, and muscular layers. The epithelial lining is composed of stratified squamous epithelia. The lamina propria has three divisions: the superficial, intermediate, and deep layers. The area between the epithelial lining and superficial lamina propria, also called Reinke's space, is the major component required for the formation of mucosal waves during phonation. In addition, the stratified squamous structure protects the superficial lamina propria against mechanic trauma. ${ }^{[18-20]}$ It has been proposed that the vocal fold epithelium has also a biomechanical function in phonation. ${ }^{[17,18]}$ In addition, the vocal fold epithelium

\begin{tabular}{|ccc|}
\multicolumn{4}{c|}{ Table 3 } \\
\multicolumn{4}{|c|}{$\begin{array}{c}\text { Pathological examination results of orthokeratotic } \\
\text { hyperkeratosis and granular layer increase }\end{array}$} \\
\hline & Study Group & Control Group \\
\hline Animal & + & - \\
1 & + & - \\
2 & + & - \\
3 & + & - \\
4 & + & \\
5 & + & \\
6 & + \\
7 & + \\
\hline
\end{tabular}

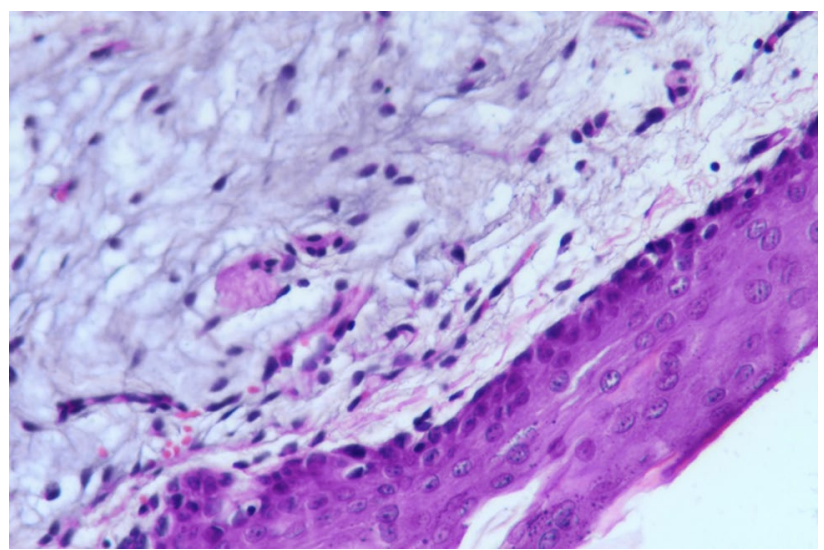

Figure 3. Epithelial lining and granular layer in control group (H-E, $\times 400)$. 
is important for ion transport and viscosity. ${ }^{[23]}$ Mucosal waves should be symmetrical and regular on both vocal folds to achieve a healthy voice. Diseases which affect the epithelial lining, such as Reinke's edema and leucoplakia, cause dysphonia without causing closure problems, but interfere with the wave formation. Increased amplitude, decreased amplitude asymmetric waves, and the absence of waves cause dysphonia. ${ }^{[24]}$ The loss of epithelial lining was experimentally shown to cause dehydration and irregular mucosal waves due to loss of ion transportation function. ${ }^{[21]}$ Previous studies on conjunctiva and nasal mucosa showed that isotretinoin caused dehydration. We consider that it can be possible for the vocal fold mucosa, as well.

Previous studies have indicated that isotretinoin decreases saliva flow ${ }^{[26]}$ and reduces goblet cells in the conjunctive and nasal epithelia. ${ }^{[5,6]}$ It has been proposed that the energy required to drive small amplitude oscillation of the vocal cord, which is designated as the phonation threshold pressure (PTP), depends on the biomechanical properties, including the thickness, elasticity, and viscosity of the vocal cords. ${ }^{[27,28]}$ The PTP reflects how easy it is to phonate and the health of the vocal folds. ${ }^{[24-26]}$ Considering hydration and viscosity and their linear relationships with PTP, the PTP can theoretically be lowered by hydration of the vocal folds after lowering the viscosity. ${ }^{[27,31]}$

There has been published cases stating that isotretinoin use may cause hoarseness in patients. ${ }^{[11-13]}$ In addition, Owners' Manual to the Voice for singers includes information about possible effects on isotretinoin on voice. ${ }^{[14]}$ Busso and Serrano ${ }^{[11]}$ and Duarte et al. ${ }^{[12]}$ reported that, after cessation of isotretinoin use, hoarseness resolved. These results can be attributed to mucosal dehydration which leads to a decrease in the wave formation and an increase in the effort for phonation by changes in PTP.

With regard to changes in the epithelial linings observed in the present study, isotretinoin may adversely affect the tissue healing in the larynx. This effect should be also studied further, particularly in voice professionals who work with heavy vocal loads, since recurrent phonotrauma may become worsen by the isotretinoin effects.

To the best of our knowledge, this is the first study to examine the effects of isotretinoin on the vocal fold. We believe that this study would facilitate further researches and suggest that isotretinoin should be used carefully in vocal performers. On the other hand, the main limitations of this study are its small sample size, relatively short follow-up, and the lack of electron microscopic analysis.
In conclusion, isotretinoin treatment for four weeks increased the granular layer of the epithelium and keratosis. Nonetheless, to reach definitive conclusions about the effects of isotretinoin use on the vocal fold mucosa of humans, high-resolution digital imaging and stroboscopic analyses should be performed in human studies with large cohorts and longer follow-up periods.

\section{Declaration of conflicting interests}

The authors declared no conflicts of interest with respect to the authorship and/or publication of this article.

\section{Funding}

The authors received no financial support for the research and/or authorship of this article.

\section{REFERENCES}

1. Thomazini BF, Dolder MA. Dose dependent treatment with isotretinoin induces more changes in the ileum than in the duodenum and jejunum in Wistar rats. Tissue Cell 2017;49:203-8.

2. Zouboulis CC. Isotretinoin revisited: pluripotent effects on human sebaceous gland cells. J Invest Dermatol 2006;126:2154-6.

3. LaytonA.Theuse of isotretinoinin acne. Dermatoendocrinol 2009;1:162-9.

4. Olutunmbi Y, Paley K, English JC 3rd. Adolescent female acne: etiology and management. J Pediatr Adolesc Gynecol 2008;21:171-6.

5. Cengiz AB, Ozyilmaz C, Tabaru A, Kayabasi S, Ege SS, Ruzgar S, et al. Effects of oral 1sotretinoin on normal and wounded nasal mucosa: an experimental study. Eur Arch Otorhinolaryngol 2018;275:3025-31.

6. de Queiroga IB, Antônio Vieira L, Barros Jde N, Melo Diniz Mde F, de Morais LC. Conjunctival impression cytology changes induced by oral isotretinoin. Cornea 2009;28:1009-13.

7. Aragona P, Cannavò SP, Borgia F, Guarneri F. Utility of studying the ocular surface in patients with acne vulgaris treated with oral isotretinoin: a randomized controlled trial. Br J Dermatol 2005;152:576-8.

8. Fraunfelder FT, Fraunfelder FW, Edwards R. Ocular side effects possibly associated with isotretinoin usage. Am J Ophthalmol 2001;132:299-305.

9. Murube J, Németh J, Höh H, Kaynak-Hekimhan P, Horwath-Winter J, Agarwal A, et al. The triple classification of dry eye for practical clinical use. Eur J Ophthalmol 2005;15:660-7.

10. Leyden JJ. The role of isotretinoin in the treatment of acne: personal observations. J Am Acad Dermatol 1998;39:S45-9.

11. Busso CI, Serrano RL. Hoarseness during isotretinoin therapy. J Am Acad Dermatol 2005;52:168.

12. Duarte I, Lazzarini R, Kobata C. Dermatological drugs, topical agents, and cosmetics. In: Arronson JK, editor. Side effects of drug annual. Vol. 31. Oxford: Elsevier; 2009. p. 287-95. 
13. Collins M, McDonald R, Stanley R, Donovan T, Bonebrake CF. Severe Paradoxical Dysphonia in Two Young Women. American Journal of Speech-Language Pathology 1993;2:52-5.

14. Gates R, Forrest LA, Obert K, editors. Owner manual to voice. A guide for singers and other professional voice users. New York: Oxford University Press; 2013.

15. Alberts DS, Coulthard SW, Meyskens FL Jr. Regression of aggressive laryngeal papillomatosis with 13-cis-retinoic acid (accutane). J Biol Response Mod 1986;5:124-8.

16. Bell R, Hong WK, Itri LM, McDonald G, Strong MS. The use of cis-retinoic acid in recurrent respiratory papillomatosis of the larynx: a randomized pilot study. Am J Otolaryngol 1988;9:161-4.

17. Hong WK, Lippman SM, Itri LM, Karp DD, Lee JS, Byers RM, et al. Prevention of second primary tumors with isotretinoin in squamous-cell carcinoma of the head and neck. N Engl J Med 1990;323:795-801.

18. Hirano M. Morphological structure of the vocal cord as a vibrator and its variations. Folia Phoniatr (Basel) 1974;26:89-94.

19. Fisher KV, Telser A, Phillips JE, Yeates DB. Regulation of vocal fold transepithelial water fluxes. J Appl Physiol (1985) 2001;91:1401-11.

20. Leydon C, Sivasankar M, Falciglia DL, Atkins C, Fisher KV. Vocal fold surface hydration: a review. J Voice 2009;23:658-65.

21. Tse JR, Zhang Z, Long JL. Effects of vocal fold epithelium removal on vibration in an excised human larynx model. J Acoust Soc Am 2015;138:EL60-4.
22. Xuan Y, Zhang Z. Influence of embedded fibers and an epithelium layer on the glottal closure pattern in a physical vocal fold model. J Speech Lang Hear Res 2014;57:416-25.

23. Levendoski EE, Leydon C, Thibeault SL. Vocal fold epithelial barrier in health and injury: a research review. J Speech Lang Hear Res 2014;57:1679-91.

24. Eddins DA, Kopf LM, Shrivastav R. The psychophysics of roughness applied to dysphonic voice. J Acoust Soc Am 2015;138:3820-5.

25. Lupi-Pégurier L, Muller-Bolla M, Fontas E, Ortonne JP. Reduced salivary flow induced by systemic isotretinoin may lead to dental decay. A prospective clinical study. Dermatology 2007;214:221-6.

26. Oikarinen K, Salo T, Kylmäniemi M, Palatsi R, Karhunen T, Oikarinen A. Systemic oral isotretinoin therapy and flow rate, $\mathrm{pH}$, and matrix metalloproteinase-9 activity of stimulated saliva. Acta Odontol Scand 1995;53:369-71.

27. Titze IR. The physics of small-amplitude oscillation of the vocal folds. J Acoust Soc Am 1988;83:1536-52.

28. Titze IR. Phonation threshold pressure: a missing link in glottal aerodynamics. J Acoust Soc Am 1992;91:2926-35.

29. Titze IR, Martin DW. Principles of Voice Production. The Journal of the Acoustical Society of America 1998;104:1148.

30. Verdolini-Marston K, Titze IR, Druker DG. Changes in phonation threshold pressure with induced conditions of hydration. Journal of Voice 1990;4:142-51.

31. Sivasankar M, Leydon C. The role of hydration in vocal fold physiology. Curr Opin Otolaryngol Head Neck Surg 2010;18:171-5. 